\title{
The Significant Role of pH in Pretreatment of SWRO Plant for Renewable Water Source
}

\author{
*M. Asif \\ *Karachi Nuclear Power Complex \\ *Corresponding Author Email: asifsaeed25@ hotmail.com
}

\begin{abstract}
This article highlighted some pretreatment methods to get potable water from Seawater. In the twentieth century, the ever-spreading urbanization and rapid increase in industrialization coupled with contamination of natural water sources through unprecedented use of chemicals have raised the demand for good quality drinkable water. The anthropogenic activities are continuously disturbing the physical, chemical, and biological composition of aquatic biota. To meet the demand of potable water, the process of Seawater Reverse Osmosis (SWRO) is now being used in developed countries. SWRO is a technique that removes all types of impurities, whether suspended or dissolved, including bacteria. This mini-review discusses some essential pretreatment parameters like $\mathrm{pH}$, conductivity, turbidity and ionic strength which are involve in SWRO to convert Seawater into drinkable. Pakistan is now in line with other countries to install SWRO plants to remove water scarcity, especially in big cities like Karachi.
\end{abstract}

Keywords: contaminated water, drinking water, SWRO, treatment plan

\section{INTRODUCTION}

The world only has 2.5 percent of fresh water in which only 1 percent of available for drinking purpose and the rest is in form of glaciers which is being melting down into the Seawater due to global warming ${ }^{1}$. Desalination is an uprising technique worldwide to meet fresh water demand and its ever-growing needs by the coming decade ${ }^{2}$. The traditional method could increase the water reservoirs up to $10 \%$ but it can't fulfill the needs in front of the ever-increasing world population's domestic and drinking purpose, spiked industrialization, agriculture growth and urban developments. The improper management of fresh water resources coupled with the increasing demand will lead us toward disastrous water scarcity soon. In the current scenario, the developed counties have been using the method of desalination of Seawater because of high salt rejection capability $(>99 \%)^{3}$. Where, thermal and membrane method for the desalination purpose has been using for about 60 and 40 years respectively ${ }^{4}$ In thermal process, desalination of Seawater is achieved by evaporation followed by condensation of water leaving salt behind. Whereas, various other method has been used in thermal desalination like Multi-Stage Flash (MSF), Multiple Effect Distillation (MED) and Vapor Compression (VC). On the other hand, in the membrane-based methods the external pressure is applied more significant than the osmotic pressure allowing only water molecule to pass through semi-permeable membrane. This method includes Reverse Osmosis (RO), Electro-Dialysis (ED), and Nano-Filtration (NF) ${ }^{5}$. It has been found that the membrane method is costeffective than the thermal method. In addition to this, the membrane method will exponentially increase in the next coming 4 years ${ }^{6}$.

For the extended-run benefits, the semi permeable membrane is protected from the scaling of minerals, fouling through organic matter and bacterial growth, and leaching of minerals ${ }^{7}$. For that initial screening of brine (Seawater) and treatment is called pretreatment, which is based on multiple procedures like $\mathrm{pH}$ adjustment, boron rejection, disinfection, coagulation, flocculation, floatation, sedimentation, filtration, antiscalant and declorination ${ }^{8}$.

\section{1. $p H$ Adjustment for Pretreatment of Feed}

The essential factors in SWRO plant based on acid-base properties like $\mathrm{pH}$, alkalinity, and boron speciation to design and operation of seawater impact critical processes such as membrane scaling biofouling, and boron permeation ${ }^{9}$. The $\mathrm{pH}$ measurement of Seawater in the manner of the vertical plan is to understand the vertical mixing of various pollutants including $\mathrm{CO}_{2}$ which has been acidifying the ocean. The values of $\mathrm{pH}$ can provide the information about stratification of euphotic zone, which helps to select the depth of brine collection ${ }^{9}$. Waly et al. ${ }^{10}$ measured the $\mathrm{pH}$ of concentrated stream, based on equations of $\mathrm{CO}_{2} \rightarrow \mathrm{HCO}_{3}^{-}+\mathrm{CO}_{3}^{2-}$ equilibrium system. Through the method of conventional pH determination, it may cause significant errors because of the higher ionic strength of seawater brine. Nir, et al. ${ }^{11}$ used Pitzer ion-interaction to evaluate the $\mathrm{pH}$ of $\mathrm{Na}^{+}$and $\mathrm{Cl}^{-}$ion dominant solution by adding $0.75 \mathrm{M} \mathrm{NaCl}$ solution to NIST buffer (National Institute of Standards and Technology) as standard which resulted in reduced pH errors i.e., below 0.03.

\section{2. $p H$ and Fouling of RO Membrane}

The carbonates, sulphates and hydroxides of $\mathrm{Ca}, \mathrm{Mg}, \mathrm{Ba}$ and $\mathrm{Sr}$ cause fouling of RO membrane via scaling on it ${ }^{12}$. To control scaling of inorganic salts the $\mathrm{pH}$ of $\mathrm{RO}$ feed decreased by introducing sulfuric acid coupled with the addition of antiscalant. In different times various antiscalants have been used i.e., SMBS (Sodium Meta Bisulphite) and sodium 
hexa meta phosphate followed by filtration ${ }^{13}$. Along with decreasing the $\mathrm{pH}$, Rahardianto, et al. ${ }^{14}$ also used calcite and gypsum seeding, manageable to achieve $30 \%$ and $93 \%$ calcium removal. But due to their eutrophicating properties, they are replaced by specific polymeric compounds as antiscalant ${ }^{8} . \mathrm{pH}$ has a significant role in the process of membrane permeability due to scaling. It is been studied that the crystallization of $\mathrm{CaSO}_{4}$ increases, in terms of size and quantity, with the increase in $\mathrm{pH}$, temperature and stirring ${ }^{15}$.

To find the precipitation of $\mathrm{CaCO}_{3}$ on the surface of membrane, method of Stiff and Davis solubility index (S\&DSI) is extensively used. It is calculated as the difference between the $\mathrm{pH}$ value of the solution to the $\mathrm{pH}$ value of the solution at equilibrium of $\mathrm{CaCO}_{3}$ with its polymorph which could be aragonite, monohydrocalcite, calcite and vaterite $^{16}$. The low $\mathrm{pH}$ combined with divalent cations largely contributes to organic fouling, resulting in permeate flux decline. As the property and dissociation of functional group directly depends upon the $\mathrm{pH}$ of the brine solution, $\mathrm{Yu}$, et al. ${ }^{17}$ observed that at $\mathrm{pH} 4$ the severe permeate flux declined whereas was found negligible in between $\mathrm{pH} 7$ to 10 . The increase in $\mathrm{pH}$ helped deprotonate the functional group of organic matter and the formation of organic-calcium complex was prevented by removing hardness.

After the scaling of the RO membrane, cleaning its surface is another task. To get rid of calcium, scaling, acidified free nitrous acid (FNA) was used at $\mathrm{pH}$ 3. FNA is a low-cost cleaning agent for both biomass and calcium removal ${ }^{18}$. Now the research has been moved towards figuring out how to protect the membrane from fouling without using antiscalants. It is been established that if the induction time of nucleation increased, it will prevent forming crystals of Ca polymorphs and the permeate flux will remain unaffected. Three different synthetic solution were prepared using $\mathrm{SO}_{4}{ }^{2-}, \mathrm{Mg}^{2+}$ and both $\mathrm{Mg}^{2+}$ and $\mathrm{SO}_{4}{ }^{2-}$, which resulted the induction time significantly increased by $1140 \%, 2820 \%$, and $3880 \%$ respectively at the $\mathrm{pH}$ of $8.3^{10}$.

Bang, et al. ${ }^{19}$ treated the feed water with $\mathrm{CO}_{2}$ at alkaline $\mathrm{pH}$, where the $\mathrm{pH}$ of solution was elevated to 10 with the help of $\mathrm{NaOH}$. The bubble of $\mathrm{CO}_{2}$ through injection was introduced into the solution which turned into $\mathrm{CO}_{3}^{-2}$ and formed white precipitates of calcium and magnesium carbonates. The $\mathrm{CO}_{2}$ bubbled until the $\mathrm{pH}$ reached 8 and the white precipitates were filtered through $0.45 \mu \mathrm{m}$ filters and this process was repeated five-time, showing the removal of all divalent cations. Cadotte, et al. ${ }^{20}$ reported a new technique to avoid scaling divalent salts on the surface of the RO membrane. The idea was to develop a method to protect the membrane without using antiscalant. Micro-nano bubbles (MNBs) of air were introduced along with membrane containing negative zeta potential (double electric layers on its surface) -34(2) $\mathrm{mV}$ at $25^{\circ} \mathrm{C}$ and operated at $\mathrm{pH}$ 7. The MNBs were sized between $90 \mathrm{~nm}$ to $900 \mathrm{~nm}$ and continued to introduce for 4 days and resulted effective against scaling.

\section{3. $\mathrm{pH}$ and Membrane Compatibility}

The process of pretreatment and varying $\mathrm{pH}$ values damages the membrane and affects its efficiency. Membrane like FT-30, a thin polymer film with microporous polysulfone, was designed for prolonging stability and tested against multiple parameters including $\mathrm{pH}$ and found undamaged in the range of $\mathrm{pH} 3$ to 11 at $60^{\circ} \mathrm{C}^{21}$. Similar to which three different RO membranes available in the market, was examined through treating with hypochlorous acid $(\mathrm{HOCl})$ by Donose, Sukumar et al. ${ }^{21}$ using Fourier transform infrared spectroscopy, Scanning Electron Microscopy and Atomic Force Microscopy. At $\mathrm{pH} 4$, two out of three resulted in rising roughness and the declining permeability of deionized (DI) water and brackish water at both $\mathrm{pH} 4$ and 7 but increased at $\mathrm{pH} 10$.

\section{4. $p H$ and Salt Rejection}

The managing membrane material is a continuous process via investigating the impact of feed water on it having different salt concentrations and impact of acidity and alkalinity. Ikeda, et al. ${ }^{22}$ reported that NTR-7400 membrane was stable for one month against $10 \mathrm{~K}$ ppm chloride ion on a pH, ranging from 1 to 13 at $80^{\circ} \mathrm{C}$. Similarly, three commercially available polyamide membranes were examined against feed pressure temperature, $\mathrm{pH}$, salt rejection, and flow rate. An increase in $\mathrm{pH}$ was directly related to the increase in salt rejection $(\mathrm{NaCl})^{23}$. The ability of permeability and salt rejection was studied via zeta potential of the RO membrane surface, which varies with the change in $\mathrm{pH}$ and greatly influences the inorganic salts and organic matters. At the $\mathrm{pH}$ level of 2 and 3, organic matter like humic acid and sodium dodecyl sulphate was noticed to be readily adsorbed on the RO membrane, showing negative zeta potential and significantly decreased salt rejection ${ }^{25}$. On the other hand, at high $\mathrm{pH}$, the membrane shows high water flux and salt rejections ${ }^{24,26}$.

\section{5. $p H$ and coagulation}

The decline in the permeate flux and the productivity of RO membrane is because of seawater turbidity, which are slightly negatively charged suspended solid particles, algae, dissolved organic matter, and colloids. Coagulation (a part of pretreatment) is when these particles are aggregated/flocculated in large size by using ferric and aluminum salts. When seawater turbidity is above 30 NTU (Nephelometric Turbidity Unit), the flocculation suspended particles, using coagulation agent, widely depend upon the $\mathrm{pH}$ 8. Initially, aluminum sulphate was used as a coagulant and effectively reduced suspended particles as the $\mathrm{pH}$ increases ${ }^{27}$. Humic acid (HA) is one of the dissolved organic matter that contributes in membrane fouling. Aluminum sulphate with a $\mathrm{pH}$ range from 4 to 10 has been used to coagulate humic acid using 3-1000 $\mu \mathrm{M}$ dosing ${ }^{28}$. Above $30 \mathrm{mg} / \mathrm{L}$ of silica as silicon dioxide cause turbidity in feed water removed by inline coagulation and filtration (ultra, micro or nano). With the same concentration of $\mathrm{SiO}_{2}$, the dosage of alum as $\mathrm{Al}_{2} \mathrm{O}_{3}$ 
used at $\mathrm{pH} 7.1$ was treated with Seawater to overcome $\mathrm{SiO}_{2}$ turbidity. On the similar $\mathrm{pH}$ the positively charged ultrafilters neutralized most of the negatively charged particles from the feed that was analyzed through energy dispersive X-ray spectroscopy ${ }^{29}$.

Salts of aluminum now rarely used as coagulant because it is too soluble in feed source (Seawater) and may cause fouling of RO membrane ${ }^{30}$. Therefore, now mostly salts of ferric are used instead, as the equilibrium of solubility of ferric ions with amorphous $\mathrm{Fe}(\mathrm{OH})_{3}$ is very low at a wide range of $\mathrm{pH}$ in seawater ${ }^{31}$. Adjustment of $\mathrm{pH}$ before the process of coagulation has a significant impact on the efficiency of treatment. Dosage of $200 \mathrm{mmol} \mathrm{L}^{-1}$ of ferric salt as $\mathrm{FeCl}_{3}$ at the $\mathrm{pH}$ of 6 helps make large floc sizes and then being filtered off easily. The competition of stable neutral molecule of ferric ion with hydroxyl ion and HA to get precipitated depends on the $\mathrm{pH}$ of the solution. In the acidic solution, the concentration of hydroxyl ion is very low compared to HA, which favors HA to bind strongly with ferric ion $^{32}$.

Including ferric ion, other hydrolyzing metal salts of calcium and magnesium can be used for coagulation which could remove the HA concentration by $95 \%$ at a pH range from 4 to $9^{33}$. Because of the hazardous effects of inorganic salts, researchers are now moving towards the alternative. A form of sugar extracted from the exterior solid skeleton of marine life like lobster, crab, fishes containing shells and shrimps called "chitosan". This has been widely used for various diseases, including high cholesterol, high blood pressure, obesity, and Crohn's disease. Chitosan is used as a coagulant and compared its results against other inorganic coagulants. It is found that the dose of $370 \mathrm{mg} / \mathrm{L}$ at $\mathrm{pH}(2-$ 11), chitosan was found more effective in the removal of turbidity as compared to $\mathrm{FeSO}_{4}$ and equally compatible to alum. Its productivity is good in an alkaline region where its maximum turbidity removal is $97.5 \%$ at the $\mathrm{pH}$ of $8.1^{34}$. Dissolved organic carbon (DOC) also contributes to irreversible RO membrane fouling and can be treated with ferric chloride solution (0.5 to $0.8 \mathrm{ppm})$ at $\mathrm{pH}(5-9)$. These DOCs can be hydrophobic or hydrophilic, and their removal is efficient at high and low $\mathrm{pH}$, respectively ${ }^{35}$.

\section{6. $p H$ and Boron Rejection}

Metalloid such as boron has pros and cons with its concentration. It has a dual effect on living organisms with a pretty small range of concentration difference for being scarce and stressful ${ }^{36}$. The sensitivity of plants towards boron is crucial, as it can help through several reactions in the nourishment of plant or could bring it to death when under the limit or stressed, respectively. Seawater typically contains boron concentration of boron i.e., about 5 to $6 \mathrm{ppm}^{37}$, because of the adverse effects of boron on living beings. WHO sets the limit of its concentration to $0.3 \mathrm{ppm}$ based on NOEL (No observed adverse effects level). Boron can be leached from the surrounding geology and weak alkali springs ${ }^{38,40}$. Boron in Seawater presents as Boric acid, a fragile acid with a value of dissociation constant (pKa) 9.2. The equilibrium ratio between boric acid $(<\mathrm{pH} 6)$ and borate $(>\mathrm{pH} 10.5)$ entirely depends upon the $\mathrm{pH}$ of Seawater. At higher concentrations, boron could result in the form of sharply water-miscible poly-nuclear ions i.e., $\left[\mathrm{B}_{3} \mathrm{O}_{3}(\mathrm{OH})_{4}\right]^{-1},\left[\mathrm{~B}_{4} \mathrm{O}_{5}(\mathrm{OH})_{4}\right]^{-2}$, $\left[\mathrm{B}_{3} \mathrm{O}_{3}(\mathrm{OH})_{5}\right]^{-2}$ and $\mathrm{B}_{5} \mathrm{O}_{6}(\mathrm{OH})_{4}{ }^{41}$.

The rejection of boron in seawater reverse osmosis is a $\mathrm{pH}$-dependent process. In acidic $\mathrm{pH}$, the boron exists in the form of boric acid, which is neutral and smaller in size and permeates quickly through membrane resulted in only 40-78\% rejection through ordinary membrane ${ }^{42}$. On the other hand, in alkaline $\mathrm{pH}$, boric acid concerts into completely hydrated borate ion, which contains anionic charge and relatively greater in size cause its rejection more than $98 \%$.

To control the concentration of boron in the permeate flow, different types of membranes have been tested against seawater feed. Along with the membranes like novel thin-film composite (TFC), the performance of membrane was examined with the additives (isopropyl alcohol) resulted in more than $92 \%$ rejection of boron at $\mathrm{pH} 7$ to $8^{43}$. The tolerance of boron could be achieved by more than $99 \%$ by increasing the $\mathrm{pH}$ level from 10.5 and above. High alkaline $\mathrm{pH}$ supports in complete conversion of boric acid via three dissociations into borate ion. At the expense of increasing $\mathrm{pH}$, the permeate flux decreases due to rapid precipitation of divalent cations $\left(\mathrm{Ca}^{+2}\right.$ and $\left.\mathrm{Mg}^{+2}\right)$, causing scaling on the surface of membrane ${ }^{44}$. The efficiency of the membrane may vary depending upon the nature of the material synthesized, including their responses toward Seawater and salty water. The elevation in $\mathrm{pH}$ value increases boron tolerance by repelled with the same negatively charged membrane and causes less diffusibility through the membrane due to increased size ${ }^{45}$.

It has been studied that the rejection of boron from Seawater is not only dependent upon $\mathrm{pH}$ but on ionic strength of feed also. At neutral pH, the boron removal was only achievable by 40 to $80 \%$, depending upon the membrane, but increasing the ionic strength of the feed water contributes to lowering the dissociation constant (pKa) from 9.25. This drop-off of $\mathrm{pKa}$ value could be helpful in boron removal at lower $\mathrm{pH}^{46}$. Tu, et al ${ }^{45}$ experimented with increasing the ionic strength of feed water up to 42.5 milli-Molar. The increase in ionic strength caused a substantial increase in boron rejection at $\mathrm{pH} 10$.

Removal of boron from feed water was also accomplished by the complexation method using various ligands and at a wide range of $\mathrm{pH}$. Initially, Mannitol, a polyolic compound used for the complexation, yields 2,2-di-borate ester and a few monoborate esters through $\mathrm{pH}$ adjustment. Boron-mannitol complex was filtered through nano-filtration at pH 9 gave more than $90 \%$ removal. In terms of basal rejection of boron as mannitol complex, was calculated through Mineql+ (Chemical Equilibrium Modeling System) indicated 97\% removal at pH $9^{47}$. Similarly, afterward, few other 
polyols (1,2-diol) chelates have been introduced, like sodium D-gluconate, D-mannitol, and $N$-methyl D-glucamine to produce dichelate ionic complexes as a function of $\mathrm{pH}$. In this type of method, the impact of $\mathrm{pH}$ and the concentration of chelates are examined based on complex formation equilibrium reactions. The effectiveness of these chelates for boron rejection was in increasing order as mentioned above but simultaneously opposite in decreasing the permeate flux ${ }^{48}$.

Various nano-filters with different porous sizes and materials are in use for boron rejection. These Nano filters (NF-45, NF-90 etc.) are now being used along with the combination of RO membranes (BW-30, TW-30 etc.). The step of adjusting $\mathrm{pH}$ (alkaline) and the placement of membranes can be different according to the researcher's point of view ${ }^{49}$. The method of passing the feed seawater through Nano-filtration (NF) followed by permeating through the RO membrane had quite success in salt rejection and boron rejection. An SWRO plant using multistage cascade with the treatment of sea water and low and high $\mathrm{pH}$ adjustments at successive stages showed the salt and boron rejection more than $95 \%{ }^{50}$. The coupling of NFs(AG $2514 \mathrm{TF}$ ) with RO membrane (HL 2514T) at the pH level of 11 resulted in the boron level in permeate less than the concentration proposed by European Union $(<1 \mathrm{ppm})$ and WHO as a non-observed effect level $(<0.3 \mathrm{ppm})^{51}$.

By comparing the designs of SWRO plants, it is observed that the double-pass configurations are effective, efficient, and stable in the long run as compared to single-pass configurations. Adjustment of $\mathrm{pH}$ in the multistage double-pass model has been controversial, whereas $\mathrm{pH}$ adjustment upto 11 in the second-pass was more reliable than low and high ${ }^{52}$. The application of Nano-filtration (NF) coupled with the RO membrane facilitated the rejection of boron and other metalloids like Arsenic (III) at the elevated $\mathrm{pH}$. Increasing the $\mathrm{pH}$ value overcomes the dissociation constant value provides remarkable tolerance against every species, including metalloids. The research examined that the rejection of As (III) was 99\% in brackish water membranes and SWRO membrane at $\mathrm{pH}=9.6$ and 40 bars and pH $=7.6$ and 24 bars, respectively ${ }^{53}$. Studies showed that the high salinity and the temperature conditions in gulf countries overcome $\mathrm{pH}$ adjustment. The double-pass SWRO model used with the readily-accessible commercial membranes exhibited the rejection of salt and boron by $99 \%$ and $91 \%$, respectively in a single pass followed by the permeate attained through second-pass meats all the requirement needed ${ }^{54}$.

\section{CONCLUSION:}

Pretreatment of SWRO is very difficult, and it depends on the physicochemical nature of a particular size and climate condition of the sea. These parameters include $\mathrm{pH}$, Turbidity, Temperature, Total Dissolved Solids (TDS), Total Suspended Solids(TSS), Dissolve Oxygen(DO), Chemical Oxygen Demand (COD), Ionic Constituents, Alkalinity, Hardness, and Microbial Counts etc. All parameters were essential to get clear water from the ultimate source of Seawater. It was concluded that the $\mathrm{pH}$ has a significant role in pretreatment and membrane permeability as the process of pretreatment and varying $\mathrm{pH}$ values damages the membrane and affects its efficiency.

\section{REFERENCES}

1. Rasul, G., Dahe, Q., \& Chaudhry, Q. Z. (2008) Pak. Jr. of Meteorology, 5(9).

2. Henthorne, AQUA (2000).

3. Brehant, A., Bonnelye, V., \& Perez, M. (2002) Desalination, 144(1-3), 353-360.

4. Valavala, R., Sohn, J., Han, J., Her, N., \& Yoon, Y. (2011) Environmental Engineering Research, 16(4), 205212.

5. Ahmed \&Hajjajb 2005.

6. Misdan, N., Lau, W. J., \& Ismail, A. F. (2012) Desalination, 287, 228-237.

7. Lin, N. H., Kim, M. M., Lewis, G. T., \& Cohen, Y. (2010) Journal of Materials Chemistry, 20(22), 4642-4652.

8. Nir, O., Ophek, L., \& Lahav, O. (2016). Environmental Science: Water Research \& Technology, 2(1), 107-116

9. Rao, D. S., \&Madhavan, N. (1964) Journal of the Marine Biological Association of India, 6(2), 217-221.

10. Waly, T., Kennedy, M. D., Witkamp, G. J., Amy, G., \& Schippers, J. C. (2011) Desalination, 280(1-3), 27-32.

11. Nir, O., Marvin, E., \& Lahav, O. (2014)Water research, 64, 187-195

12. Rahman, F. (2013) Desalination, 319, 79-84.

13. Reverberi, F., \&Gorenflo, A. (2007) Desalination, 203(1-3), 100-106.

14. Rahardianto, A., Gao, J., Gabelich, C. J., Williams, M. D., \& Cohen, Y. (2007) Journal of Membrane Science, 289(1-2), 123-137.

15. Choi, Y., Naidu, G., Jeong, S., Lee, S., \& Vigneswaran, S. (2018) Desalination, 426, 78-87.

16. Peña, J., Buil, B., Garralon, A., Gomez, P., Turrero, M. J., Escribano, A., ... \& Gómez, M. A. (2010) Desalination, 254(1-3), 75-79.

17. Yu, Y., Lee, S., \& Hong, S. (2010) Journal of Membrane Science, 351(1-2), 205-213.

18. Filloux, E., Wang, J., Pidou, M., Gernjak, W., \& Yuan, Z. (2015) Journal of membrane science, 495, $276-283$.

19. Bang, J. H., Yoo, Y., Lee, S. W., Song, K., \& Chae, S. (2017)Minerals, 7(11), 207.

20. Cadotte, J. E., Petersen, R. J., Larson, R. E., \& Erickson, E. E. (1980) Desalination, 32, 25-31.

21. Donose, B. C., Sukumar, S., Pidou, M., Poussade, Y., Keller, J., \&Gernjak, W. (2013) Desalination, 309, $97-$ 105. 
22. Ikeda, K., Nakano, T., Ito, H., Kubota, T., \& Yamamoto, S. (1988) Desalination, 68(2-3), 109-119.

23. Van Wagner, E. M., Sagle, A. C., Sharma, M. M., \& Freeman, B. D. (2009)Journal of Membrane Science, 345(1-2), 97-109.

24. Childress, A. E., \& Deshmukh, S. S. (1998)Desalination, 118(1-3), 167-174.

25. Hoang, T., Stevens, G., \& Kentish, S. (2010) Desalination, 261(1-2), 99-103.

26. La, Y. H., Sooriyakumaran, R., Miller, D. C., Fujiwara, M., Terui, Y., Yamanaka, K., ... \& Allen, R. D. (2010) Journal of Materials Chemistry, 20(22), 4615-4620.)

27. Tsuge, H., Suda, S., \& Matsumura, T. (1981) Desalination, 38, 425-436.

28. Duan, J., Wang, J., Graham, N., \& Wilson, F. (2002) Desalination, 150(1), 1-14.

29. Cheng, H. H., Chen, S. S., \& Yang, S. R. (2009) Separation and Purification Technology, 70(1), 112-117.

30. Tabatabai, S. A. A., Schippers, J. C., \& Kennedy, M. D. (2014) water research, 59, 283-294.

31. Edzwald, J. K., \&Haarhoff, J. (2011)Water research, 45(17), 5428-5440.

32. Duan, J., Graham, N. J. D., \& Wilson, F. (2003) Water science and technology, 47(1), 41-48.

33. Duan, J., Niu, A., Shi, D., Wilson, F., \& Graham, N. J. D. (2009) Desalination and Water Treatment, 11(1-3), 173-183.

34. Altaher, H. (2012) Journal of hazardous materials, 233, 97-102.

35. Jeong, S., Sathasivan, A., Kastl, G., Shim, W. G., \& Vigneswaran, S. (2014) Chemosphere, 95, 310-316.

36. Parks, J. L., \& Edwards, M. (2005) Critical Reviews in Environmental Science and Technology, 35(2), 81-114.

37. Nadav, N. (1999) Desalination, 124(1-3), 131-135.

38. Magara, Y., Tabata, A., Kohki, M., Kawasaki, M., \& Hirose, M. (1998) Desalination, 118(1-3), 25-33

39. Pastor, M. R., Ruiz, A. F., Chillon, M. F., \& Rico, D. P. (2001) Desalination, 140(2), 145-152.

40. Kabay, N., Güler, E., \&Bryjak, M. (2010) Desalination, 261(3), 212-217

41. Sagiv, A., \&Semiat, R. (2004) Journal of Membrane Science, 243(1-2), 79-87.

42. Liu, M., Yu, S., Tao, J., \& Gao, C. (2008) Journal of Membrane Science, 325(2), 947-956.

43. Koseoglu, H., Kabay, N., Yüksel, M., \&Kitis, M. (2008) Desalination, 223(1-3), 126-133.

44. Oo, M. H., \& Song, L. (2009). Desalination, 246(1-3), 605-612.

45. Tu, K. L., Nghiem, L. D., \& Chivas, A. R. (2011) Chemical Engineering Journal, 168(2), 700-706.

46. Rahmawati, K., Ghaffour, N., Aubry, C., \& Amy, G. L. (2012)Journal of membrane science, 423, 522-529.

47. Geffen, N., Semiat, R., Eisen, M. S., Balazs, Y., Katz, I., \&Dosoretz, C. G. (2006) Journal of Membrane Science, 286(1-2), 45-51.

48. Dydo, P., Nemś, I., \&Turek, M. (2012) Separation and purification technology, 89, 171-180.

49. Dydo, P., Turek, M., Ciba, J., Trojanowska, J., \&Kluczka, J. (2005)Desalination, 185(1-3), 131-137.

50. Tu, K. L., Nghiem, L. D., \& Chivas, A. R. (2010) Separation and Purification Technology, 75(2), 87-101.

51. Mnif, A., Hamrouni, B., \& Dhahbi, M. (2009) Desalination and Water Treatment, 5(1-3), 119-123.

52. Yavuz, E., Arar, Ö., Yüksel, M., Yüksel, Ü., \& Kabay, N. (2013) Desalination, 310, 135-139.

53. Teychene, B., Collet, G., Gallard, H., \&Croue, J. P. (2013) Desalination, 310, 109-114.

54. Farhat, A., Ahmad, F., Hilal, N., \& Arafat, H. A. (2013) Desalination, 310, 50-59. 